\title{
Phenomenal Conservatism and the Subject's Perspective Objection
}

\author{
Logan Paul Gage ${ }^{1}$
}

Received: 8 January 2014 / Accepted: 22 April 2015 / Published online: 2 August 2015

(C) Springer Science+Business Media Dordrecht 2015

\begin{abstract}
For some years now, Michael Bergmann has urged a dilemma against internalist theories of epistemic justification. For reasons I explain below, some epistemologists have thought that Michael Huemer's principle of Phenomenal Conservatism (PC) can split the horns of Bergmann's dilemma. Bergmann has recently argued, however, that PC must inevitably, like all other internalist views, fall prey to his dilemma. In this paper, I explain the nature of Bergmann's dilemma and his reasons for thinking that PC cannot escape it before arguing that he is mistaken: PC can indeed split its horns.
\end{abstract}

Keywords MichaelBergmann · Michael Huemer-Phenomenal Conservatism - Subject's Perspective Objection · Bergmann's dilemma for internalism

\section{Introduction}

Few epistemic principles in recent memory have generated as much interest and controversy as Michael Huemer's Phenomenal Conservatism:

(PC): If it seems to $S$ that $p$, then, in the absence of defeaters, $S$ thereby has at least some degree of justification for believing that $p$. (Huemer 2007: 30)

As such, it has been the target of several objections. Some worry that PC must be false because it implies that even crazy seemings or appearances can justify (Markie 2005: 357; Littlejohn 2011; Tooley 2013). Other philosophers fear that without a metajustification for thinking that one's seemings are reliable-i.e., a justification for one's justification-PC must be mistaken (BonJour 2004: 357-360; Steup 2013). And still others have worried that because one's seemings can be cognitively penetrated by

Logan Paul Gage

lgage@franciscan.edu

1 Franciscan University of Steubenville, 1235 University Boulevard, Steubenville, OH 43952, USA 
wishful thinking and irrational beliefs and desires, surely not all seemings provide prima facie justification (Markie 2006: 119-120; Lyons 2011; McGrath 2013; Siegel 2013). In my view however, each of these challenges has been met with plausible replies by advocates of Phenomenal Conservatism. ${ }^{1}$ Yet there is one very serious challenge to PC that has not been met head-on. In this paper, I will consider what is perhaps the most important recent objection to internalism generally and conservative principles like PC more specifically: Michael Bergmann's dilemma for internalism.

Bergmann has urged a dilemma against all internalist theories of epistemic justification (Bergmann 2006) and against Phenomenal Conservatism in particular (Bergmann 2013). In essence, Bergmann has argued that all internalist theories of justification either end in regress and skepticism or else are unmotivated. Michael Huemer has not directly responded to Bergmann's challenge. ${ }^{2}$ So I will attempt to respond on his behalf. First, I set the broader context by explicating the nature of Bergmann's dilemma for internalism. Second, I explain Bergmann's specific application of his dilemma for internalism to Phenomenal Conservatism. Third, I suggest what I deem to be plausible replies to Bergmann's arguments against both weak and strong versions of PC. In short, I will argue that PC can indeed split the horns of Bergmann's dilemma. I close with a reflection on the nature of Bergmann's dilemma and its prospects for success even if my counter-arguments are unsuccessful.

\section{Bergmann's Dilemma for Internalism}

It must be said up front that defining internalism and externalism has led to no small controversy in recent epistemology. But as Bergmann understands internalism, it is a position requiring an awareness condition on justification. As he puts it, internalism is the thesis that, "in order for a person's belief to be epistemically justified, it is not enough that it has certain virtues (such as being in accord with the evidence or being caused by the fact that makes it true); in addition, that person must be in some sense aware of those virtues" (Bergmann 2006: 3). This awareness, however, need not be actual. Potential awareness - awareness that one is able to gain by armchair reflection alone - is also acceptable on many internalist accounts. Thus, what most kinds of internalism seem to have in common, thinks Bergmann (2006: 9), is that a subject must be at least potentially aware of something contributing to her justification in order for her belief to be justified. Specifically, Bergmann conceives of this necessary condition of awareness in the following way:

The Awareness Requirement: $S$ 's belief is justified only if (i) there is something, $X$, that contributes to the justification of $B$ - e.g., evidence for $B$ or a truth indicator for $B$ or the satisfaction of some necessary condition of $B$ 's justification - and (ii) $S$ is aware (or potentially aware) of $X$. (Bergmann 2006: 9; cf. 2006: 55-57)

\footnotetext{
${ }^{1}$ For a short and recent summary of replies to these challenges, see Huemer (2013b).

${ }^{2}$ When the opportunity arose, Huemer had very little to say (Huemer 2013a: 336-337).
} 
Some prominent internalists would likely dispute the idea that an awareness requirement is an essential feature of internalism (e.g., Conee and Feldman 2004). ${ }^{3}$ Still, Bergmann's understanding of internalism does capture the heart of what many prominent internalists like Laurence Bonjour (BonJour and Sosa 2003: 24) see as distinctive about internalism.

At this point, Bergmann offers a dilemma for internalism - one which clearly parallels the Sellarsian dilemma for foundationalism (Sellars 1963, 1975; cf. BonJour 1978, 1985). Internalism comes in two main varieties: strong and weak, depending on the strength of awareness that the internalist requires for justified belief. Regardless of which kind of awareness the internalist adopts, Bergmann argues, problems arise. Simply put, strong internalism leads to a vicious regress because of a meta-level awareness requirement, and weak internalism cannot meet its own criteria of success and hence is unmotivated. Bergmann (2006: 13-14) formalizes his argument against internalism as follows:

(I) An essential feature of internalism is that it makes a subject's actual or potential awareness of some justification-contributor a necessary condition for the justification of any belief held by that subject.

(II) The awareness required by internalism is either strong awareness or weak awareness.

(III) If the awareness required by internalism is strong awareness, then internalism has vicious regress problems leading to radical skepticism.

(IV) If the awareness required by internalism is weak awareness, then internalism is vulnerable to the SPO [Subject's Perspective Objection], in which case internalism loses its main motivation for imposing the awareness requirement.

(V) If internalism either leads to radical skepticism or loses its main motivation for imposing the awareness requirement (i.e., avoiding the SPO), then we should not endorse internalism.

(VI) Therefore, we should not endorse internalism.

In defense of premise (V), Bergmann argues that other attempts to motivate internalism fail-a claim to which we will return. ${ }^{4}$ But if that is the case, the key premises needing defense are those constituting the heart of the dilemma, namely premises (III) and (IV).

Let us begin with the strong awareness requirement and Bergmann's defense of premise (III). Strong awareness "is awareness that involves conceiving of the justification-contributor that is the object of awareness as being in some way relevant to the truth or justification of the relevant belief" (Bergmann 2006: 14). This strong awareness comes in both doxastic and non-doxastic versions. Doxastic strong awareness is "awareness that involves the belief that the object of awareness is in some way relevant to the truth or justification of the relevant belief" (Bergmann 2006: 14). The

\footnotetext{
${ }^{3}$ In fact, it should be noted that several prominent internalists reject access requirements. See, for example, Fumerton (1995: 81) and other direct acquaintance theorists. For different but relevant understandings of internalism, see Fumerton (1995: 60-66) and Huemer (2011b: 11).

${ }^{4}$ Chapter four of Bergmann (2006) argues against a positive, deontological motivation for internalism, while chapters seven and eight consider criticisms of externalism other than the SPO which might be considered as negative motivations for internalism.
} 
problem, according to Bergmann, is that this belief that the object of awareness is in some way relevant must itself be justified; otherwise, there is no point in requiring the belief at all (Bergmann 2006: 15). But, this creates a vicious regress (Bergmann 2006; Steup 2013). Once this meta-requirement is in place, the need for a justified meta-metabelief and a justified meta-meta-meta-belief arises. Unless one opts for infinitism about beliefs, this requirement seems untenable (Bergmann 2006: 14-16). One might try to escape this conclusion by claiming that $S$ need only be potentially able to justifiably believe that the justifier in question justifies $S$ 's original belief. But Bergmann (2006: 16-19) argues that this view ends in vicious regress as well, since it requires the potential for an infinite number of beliefs of ever-increasing complexity. ${ }^{5}$

As mentioned above, Bergmann (2006: 17-19) also considers non-doxastic versions of strong awareness where $S$ conceives of the justifier as a justifier but has no beliefs about the justifier being justified. Non-doxastic strong awareness could also come in actual and potential varieties depending on whether $S$ justifiably but non-doxastically conceives that the justifier justifies or whether $S$ only has the ability to so justifiably conceive. Bergmann thinks both routes also end in vicious regress. Non-doxastic strong awareness, he argues, will require either the actual or potential application of an infinite number of concepts.

Weak internalism, on the other hand, avoids the regress problem only to create another, according to Bergmann. This problem constitutes the second horn of Bergmann's dilemma for internalism. Rather than require a meta-belief about one's reason to believe that $p$ (or a meta-concept application), weak internalism only requires an awareness of the reason for believing that $p$. This awareness can take many forms, but the hallmark of weak awareness is that it does not require conceiving of the justifier as a justifier. For this very reason, however, in defense of premise (IV), Bergmann maintains that weak internalism is too weak to motivate internalism. It falls prey to a common objection internalists often make against externalism.

Bergmann (2006: 11-12) asks us to reconsider BonJour's famous argument against reliabilist versions of externalism from Norman the clairvoyant. BonJour writes:

Norman, under certain conditions which usually obtain, is a completely reliable clairvoyant with respect to certain kinds of subject matter. He possesses no evidence or reasons of any kind for or against the general possibility of such a cognitive power or for or against the thesis that he possesses it. One day Norman comes to believe that the President is in New York City, though he has no evidence either for or against this belief. In fact, the belief is true and results from his clairvoyant power under circumstances in which it is completely reliable. (BonJour 1985: 41)

The lesson, of course, is supposed to be that (contra reliabilism) Norman clearly lacks justification for his reliable clairvoyant beliefs. Making this point explicit, BonJour tells us that the problem is that, from Norman's own perspective, the fact that

\footnotetext{
${ }^{5}$ Crisp (2010) argues that the meta-beliefs do not actually increase in complexity. For this reason, he concludes that Bergmann has given no reason to think the regress induced is actually vicious. Hence, Bergmann's premise (III) above is unmotivated. One need only have the potential to believe one of these meta-beliefs to be justified; and this, he claims, is fully possible. For a critical reply to Crisp, see DePoe (2012: 414-416).
} 
Norman's belief is true is "an accident." Sure, an external observer might see that Norman's belief is not an accident but results from a reliable cognitive faculty. Yet, BonJour wonders, "how is this supposed to justify Norman's belief?" After all, from Norman's own perspective, the belief surely is accidentally true, and "the rationality or justifiability of Norman's belief should be judged from Norman's own perspective rather than from one which is unavailable to him" (BonJour 1985: 43-44; cf. BonJour and Sosa 2003: 27-32). ${ }^{6}$

In BonJour's argument, Bergmann (2006: 12) sees the following internalist objection to externalism:

The Subject's Perspective Objection: If the subject holding a belief isn't aware of what that belief has going for it, then she isn't aware of how its status is any different from a stray hunch or an arbitrary conviction. From that we may conclude that from her perspective it is an accident that her belief is true. And that implies that it isn't a justified belief.

The problem, according to Bergmann, is that weak internalism cannot itself satisfy this widespread conviction of internalists; weak internalism is subject to the SPO. Norman the clairvoyant has a reason for his true belief that the president is in NYC, yet he is still not justified because the truth of his belief is "accidental" in some sense. But without a meta-requirement like that found in strong internalism (which requires that the subject be aware of her reason for believing that $p$ qua reason), Bergmann argues that many ordinary beliefs will be accidental when considered from a subjective perspective. If this is correct, having an undefeated reason for believing that $p$ is insufficient for doxastic justification.

To better see the problem for weak internalism, consider the form of what Matthias Steup (2013: 140) dubs "Bergmann Cases" (i.e., cases where weak internalism does not meet the SPO).

(i) $S$ has a true belief that $p$.

(ii) $S$ has a reason $r$ for $p$.

(iii) $S$ does not have any form of justified meta-belief with the content that $r$ is a source of justification for his belief that $p$.

(iv) Because of (iii), the truth of $S$ 's belief must, from within $S$ 's perspective, be considered accidental.

(v) Because of (iv), $S$ 's belief fails to be justified by the very standards internalists themselves endorse.

Here, $S$ has a reason $r_{1}$ for believing that $p$ but not a reason $r_{2}$ for believing $r_{1}$ to justify his belief that $p$. The idea is that by meeting (i)-(iii), $S$ is justified according to weak internalism, but in reality, $S$ is surely unjustified according to a common criteria (the SPO) which internalists typically urge against externalists. If such cases are possible, weak internalism cannot meet internalism's own standard for success.

\footnotetext{
${ }^{6}$ As Bergmann notes, this sort of awareness requirement is seen in several other internalists as well (e.g., Lehrer 1990: 162; Moser 1985: 129).
} 


\section{PC to the Rescue?}

It has seemed to some advocates of Phenomenal Conservatism that PC can escape Bergmann's dilemma. After all, PC does not require any sort of meta-belief for justification. Recall that according to Huemer's current formulation, it only states the following:

(PC): If it seems to $S$ that $p$, then, in the absence of defeaters, $S$ thereby has at least some degree of justification for believing that $p$. (Huemer 2007: 30)

As others have explained, a seeming is an experience of a special sort - one that has propositional content and a distinctive phenomenal character which has "the feel of truth" (Tolhurst 1998: 298; cf. Huemer 2001: 77-79; Gage 2014: 27-32). One might easily think that PC escapes the horns of Bergmann's dilemma: it gives an internalist notion of justification which neither leads to regress (through requiring a meta-belief) nor seems accidental from the subject's point of view, rooted as it is in the way the world seems to the subject.

Bergmann, however, argues that PC also falls prey to his dilemma. It is this contention that I wish to dispute in the remainder of this paper. But first we must see why Bergmann thinks that PC cannot avoid his dilemma for internalism. Bergmann begins by pressing on Huemer's definition of PC. He argues that if Huemer intends PC to be an internalist notion of justification (i.e., one which excludes externalism), then he must really have in mind the view that $S$ 's belief that $p$ is doxastically justified if and only if the belief is based on $S$ 's seeming that $p$ (Bergmann 2013: 154-155). This seems fair enough since at times Huemer (e.g., Huemer 2001: 109) suggests that PC is the only viable principle of non-inferential justification. Just think of Huemer's self-defeat argument (Huemer 2001: 107-108; Huemer 2007: 39-41; Huemer 2011a, b). He argues that ultimately only seemings can justify. Huemer (2006: 148) also endorses the "appearance account" of internalism which maintains that "all of the conditions that confer justification supervene on how things seem to the subject." Hence, it seems likely that he would endorse the stronger, internalist 'if and only if' principle.

Given this specifically internalist notion of PC, Bergmann distinguishes two possible formulations of internalist Phenomenal Conservatism (IPC) depending on the sort of awareness requirement they place on PC. IPC might claim that $S$ must conceive of $S$ 's seeming as in some way relevant to the truth or justification of the belief (strong version), or it might not (weak version). Hence, he distinguishes these two possible versions of IPC with the ultimate aim of showing that both fall victim to the two horns of his more general dilemma for internalism. The strong version is as follows:

$\left(\mathrm{IPC}_{\mathrm{S}}\right): S$ 's belief that $p$ is prima facie justified only if (1) it seems to $S$ that $p$, (2) $S$ is aware of this seeming (i.e., it is a conscious seeming ${ }^{7}$ ), and (3) $S$ conceives of this seeming that $p$ as being in some way relevant to the truth or justification of the belief that $p$. (Bergmann 2013: 164)

\footnotetext{
${ }^{7}$ On Bergmann's inclusion of the word "conscious" here, see Bergmann (2013: 160-162). By a conscious seeming, he just means a seeming that is within your first-person perspective. You need not be aware that you are having a seeming to have a conscious seeming; you need only be aware of the seeming from the inside, so to speak. In what follows, I just assume that all seemings are conscious since I am unsure what an unconscious seeming is.
} 
The weak version, however, requires no such conceiving of the seeming as relevant to the truth or justification of the belief.

(IPC $\mathrm{I}_{\mathrm{W}}$ ): $S$ 's belief that $p$ is prima facie justified only if (1) it seems to $S$ that $p$ and (2) $S$ is aware of this seeming (i.e., it is a conscious seeming); it is not necessary that (3) $S$ conceives of this seeming that $p$ as being in some way relevant to the truth or justification of the belief that $p$. (Bergmann 2013: 163)

Here, we have PC instantiations of Bergmann's original targets: strong and weak internalism. With these two versions of internalist PC clarified, Bergmann argues that $\mathrm{PC}$ is bound to fall prey to his general dilemma against internalism. In what follows, I consider and evaluate his arguments that both $\mathrm{IPC}_{\mathrm{S}}$ and $\mathrm{IPC}_{\mathrm{W}}$ cannot meet this challenge.

\section{$4 \mathrm{PC}$ and Bergmann's Dilemma, Part I: $\mathrm{IPC}_{\mathrm{S}}$}

Put most simply, the problem facing advocates of the strong version-i.e., those who advocate clause (3) of $\mathrm{IPC}_{\mathrm{S}}$ - is this: They must either think that (a) the subject's conceiving must itself be justified, or they must think that (b) this conceiving need not be justified (Bergmann 2013: 164). If they do think it must be justified, then Bergmann argues that they end up in an infinite regress just like those who require a meta-belief about one's justification - for their judgment that their conceiving is justified must be justified and so on. But if IPC $\mathrm{S}_{\mathrm{S}}$ 's advocates claim that the conceiving involved does not itself need to be justified, then why think that this conceiving is a necessary condition on justification? After all, Bergmann asks, what could it possibly contribute to the justification of the target belief if it is not itself justified?

Let us consider option (a) first. Bergmann's concern here is that if only seemings can justify, then in order for a given belief to be doxastically justified, it must be the case that (i) $S$ has a seeming that $p$, (ii) this seeming is conscious, (iii) $S$ conceives of the seeming that $p$ as relevant to the justification of $S$ 's belief that $p$, and (iv) $S$ is justified in step (iii) - that is, $S$ is justified in conceiving of the seeming that $p$ as relevant to the belief that $p$. In order for step (iii) to be justified, Bergmann says, one must apply a concept like "being relevant" to the seeming. But if that concept application is itself to be justified, then it too needs a seeming. An infinite regress is created because, on this view, if a seeming is to be useful in justifying a belief, then it needs a concept application; and each concept application needs a seeming to justify it (Bergmann 2013: 164-166). So, seeming $S_{1}$ needs concept application $A_{1}$. But then concept application $A_{1}$ needs another seeming $S_{2}$. But then one needs concept application $A_{2}$ in order to be justified in connecting $S_{2}$ to $A_{1}$, etc., etc. While I will not do so in this paper, it is worth noting that some have challenged the notion that the ensuing regress is vicious (Rogers and Matheson 2011; Crisp 2010; Fales 2014). ${ }^{8}$

More interesting for my purposes is interpretation (b) of the strong version of IPC. Recall that this version agrees that the subject must somehow conceive of her seeming

\footnotetext{
${ }^{8}$ Bergmann (2006: 38-43) replies to Fales's (1996) argument that the regress here is not vicious. Fales (2014) extends this debate.
} 
that $p$ as relevant to the justification or truth of her belief that $p$, but crucially, this conceiving itself need not be justified. Bergmann (2013: 164) thinks that it is simply implausible to think that a conception which is not itself justified is somehow a necessary condition for doxastic justification. After all, what could this conceiving possibly contribute to a belief's justification if it is not itself justified? Say that $S$ satisfies clauses (1) and (2) of $\mathrm{IPC}_{\mathrm{S}}$. That is, suppose $S$ has a conscious seeming that $p$. Bergmann notes that $S$ could then meet clause (3) of IPC $_{\mathrm{S}}$ simply by incorrectly (or even irrationally) conceiving of the seeming that $p$ as relevant to the justification of her belief. If (1) and (2) are not sufficient for doxastic justification, what could a mistaken (or even crazy) concept application add such that the belief is then doxastically justified (Bergmann 2013: 166)?

In my view, the advocate of $\mathrm{IPC}_{\mathrm{S}}$ should not be troubled by this objection. To answer this worry, we must show that conceiving of a seeming that $p$ as relevant to the justification of the target belief can plausibly contribute something to the justification of the belief that $p$ - and, furthermore, that it can do so without falling victim to a vicious regress. ${ }^{9}$ Given the above argument and others from Bergmann (e.g., 2005: 431, 2006: $15)$, it is reasonable to think that his leading intuition is that if this concept application cannot add anything to what is known as "the truth connection" (cf. Cohen 1984; BonJour 1985: 7-8; Bergmann 2006: 141-143) - i.e., to the likely truth of the belief in question - then such a concept application adds nothing to a belief's justification. That is, if $x$ fails to add anything to the truth connection-i.e., if $x$ fails to make it more likely that the target proposition is true - then it would be absurd to think that it is a necessary condition on justification.

So, to repeat Bergmann's challenge to interpretation (b) of $\mathrm{IPC}_{\mathrm{S}}$ : If clauses (1) and (2) are not sufficient for doxastic justification, what could a mistaken (or even crazy) concept application add such that the belief is then doxastically justified? Well, without doubt, such a mistaken concept application does not add to the truth connection. Yet even if securing the truth connection is necessary for justification, surely securing the truth connection is not the only purpose of a condition on justification. As Chris Tucker (2012: 328) reminds us, the basing relation is a widely accepted necessary condition on justification that does not strengthen the truth connection: "Basing a belief in $\mathrm{P}$ on a belief in E contributes to the...justification of my belief in $\mathrm{P}$, not because it makes the belief more likely to be true, but because it constitutes, at least in part, the required mental connection between my belief in E and my belief in P." So, a necessary condition on justification like the basing relation, then, might help us secure the required mental connection for justification - a connection, roughly, which relates one's evidence to one's belief. To illustrate the need for such a mental connection, consider two cases from Fumerton (2004a: 154) in which a subject infers a new belief $p$ from some evidence $e$ (where $e$ entails $p$ ). In the first case, $S_{1}$ 'sees' that $e$ logically entails $p$. In the second case, $S_{2}$ is caused to believe $p$ as a result of believing $e$ and yet does not see how $e$ entails $p$ (perhaps it is a very complicated inference). Few of us, I think, would judge $S_{2}$ 's belief that $p$ epistemically justified. $S_{2}$ simply lacks the right sort of mental connection between his evidence and his belief.

Return now to Bergmann's line of reasoning. Perhaps Bergmann is right that a wildly inaccurate concept application adds nothing to the truth connection. But as we

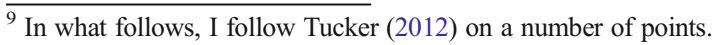


have just seen, there is no reason to think that condition (3) of $\mathrm{ICP}_{\mathrm{S}}$-i.e., that $S$ must conceive of this seeming that $p$ as being in some way relevant to the truth or justification of the belief that $p$-can be a necessary condition on justification only if it contributes to the likely truth of $p$. A concept application which appears correct from the subject's perspective (even if it is mistaken) adds something important to one's justification by securing a mental connection such that the justification contributor and the belief are appropriately connected. The advocate of interpretation (b) of $\mathrm{ICP}_{\mathrm{S}}$ could, then, reasonably maintain that justification requires a conscious seeming that $p$ plus a higher-order conception of her seeming that $p$ as being relevant to the justification or truth of her belief that $p$ (regardless of whether this conception is itself justified). After all, even a mistaken concept application might secure this mental connection. Further, the advocate of interpretation (b) of IPC $_{S}$ does not fall prey to a vicious regress. This regress was only generated by assuming that the conceiving of the seeming as relevant to the belief must be justified. But interpretation (b) of $\mathrm{IPC}_{\mathrm{S}}$ does not assume this in the first place. If this is correct, then Bergmann has given no reason to dissuade the advocate of $\mathrm{IPC}_{\mathrm{S}}$ that such a requirement like (3) is necessary.

\section{PC and Bergmann's Dilemma, Part II: IPC $_{W}$}

But even if the foregoing reply to Bergmann regarding $\mathrm{IPC}_{\mathrm{S}}$ is correct, Bergmann's dilemma might still have great force. After all, as Bergmann (2013: 167) himself notes - and I concur - most advocates of PC are unlikely to be dismayed by his argument against IPC $_{S}$ since "they have never been particularly enamored with higher-level requirements such as clause (3)" of $\mathrm{IPC}_{\mathrm{S}}$. For this reason, he focuses most of his attention on $\mathrm{IPC}_{\mathrm{W}}$. Just as with other versions of weak internalism, Bergmann argues that $\mathrm{IPC}_{\mathrm{W}}$, given its weak awareness requirement, will fall victim to the SPO. If this is correct, Bergmann continues, the motivation for internalist PC will be undermined, as the SPO was the main motivation for internalism in the first place. Therefore, $\mathrm{IPC}_{\mathrm{W}}$ should not be endorsed.

Let us examine this argument in more detail. The SPO is meant to be an objection to externalism and hence a (negative) motivation for internalism. It is meant to show that even if a belief has something going for it — say, it is reliably formed or produced by properly functioning faculties - this is still not enough for the belief to be justified. Something more than externalist virtue is needed for epistemic justification. Bergmann (2013: 168) describes the heart of the SPO as follows:

(SPO): If the believing subject isn't aware of what her belief has going for it, then from her perspective, it is an accident that the belief is true, in which case the belief isn't justified. (cf. BonJour 1985: 42-44; Bergmann 2006: 11-12)

But, what exactly does it mean for a belief to be an accident from the subject's perspective? In his earlier work, Bergmann (2006) did not attempt an analysis. But more recently Bergmann (2013: 168-170) considers four possibilities before settling on the following notion: 
(Accident V) It's false that it's an accident from $S$ 's perspective that her belief $B$ is true iff: $S$ is aware of $X$ and $S$ believes that $X$ indicates B's truth (or at least conceives of $X$ as being relevant to B's truth or justification). (Bergmann 2013: 168)

Bergmann (2013: 169) thinks this interpretation of what it means to be an accident from the subject's perspective is best in that if you satisfy Accident V, then the target belief is clearly not an accident from the subject's perspective, while on other accounts, this is not the case; so the SPO is best interpreted with Accident V's understanding of accidentality in mind. The problem with BonJour's Norman, in this view, is that Norman is either not aware of something $X$ which indicates the truth of his belief and/or Norman does not believe that $X$ is (or at least conceive of $X$ as) relevant to the truth of his belief.

We will return to this issue shortly. But with this view of the SPO in mind, we can now see why Bergmann thinks IPC $\mathrm{W}_{\mathrm{W}}$ cannot escape his dilemma for internalism: $\mathrm{IPC}_{\mathrm{W}}$ is simply unable to avoid the SPO. As a result, it is unmotivated and hence should not be believed. To see this, recall that according to $\mathrm{IPC}_{\mathrm{W}}$ all that doxastic justification for the belief that $p$ requires is that $S$ has a conscious seeming that $p$. It is not required that $S$ conceive of this seeming that $p$ as relevant to the truth or justification of $S$ 's belief that $p$. Bergmann (2013: 170) rightly notes that the question before us is this: Can $S$ have a conscious seeming that $p$ while at the same time the truth of $p$ is an accident from $S$ 's perspective?

Bergmann thinks that the answer is surely 'yes.' He imagines situations in which $S$ has an objectively good reason to believe that $p$, and does indeed believe that $p$, but $S$ does not recognize the good reason to believe that $p$ as a good reason to believe that $p$. For instance, Bergmann (2013: 170) says, one might have pains that are indicative of a heart attack; believe that one is having a heart attack; and yet believe that one is having a heart attack for silly reasons (e.g., one just heard Enrique Iglesias's song "Heart Attack" on the radio). So, what is the problem here? Well, the truth of the belief that $p$ seems accidental from $S$ 's perspective (i.e., given the reasons for which $S$ actually believes that $p$ ).

So Bergmann thinks that it is surely possible for $S$ to have a conscious seeming that $p$ while at the same time the truth of $p$ is an accident from $S$ 's perspective. As another example, imagine that Sam, because of some severe cognitive malfunction, cannot see the connections in modus ponens. In such a case, Sam might believe that $p$, believe that $p$ entails $q$, and believe that $q$ without basing the belief that $q$ on the relevant propositions and modus ponens. In the same way, Bergmann (2013: 171172) thinks, "it is possible to hold the belief that $p$ for a silly reason and at the same time to be aware of the seeming that $p$, all the while (because of severe malfunction) not recognizing any connection between the seeming that $p$ and the truth of the belief that $p . "$

But if this is possible, then "the believer will have a conscious seeming that $p$ and yet it will be an accident from that person's perspective that her belief that $p$ is true" (Bergmann 2013: 172). So if Bergmann is right, it is indeed possible to have a conscious seeming that $p$ and, at the same time, for one's belief that $p$ to be only accidentally true from one's own perspective. And if this is possible, then IPC $_{\mathrm{W}}$ is too weak to avoid the SPO. As the whole point of internalism in Bergmann's view was to 
posit the need for an awareness requirement on justification and hence avoid the SPO, the fact that $\mathrm{IPC}_{\mathrm{W}}$ cannot itself avoid the SPO is a major problem. If the point of rejecting externalist theories of justification was because the beliefs fall prey to the SPO - i.e., externally justified beliefs can be accidental from the subject's perspective - then the advocate of IPC $\mathrm{W}_{\mathrm{W}}$ has just as good of a reason to reject IPC $\mathrm{W}$ as to reject externalism. In this regard, $\mathrm{IPC}_{\mathrm{W}}$ is simply unmotivated.

In reply, however, Bergmann's critique of IPC $_{\mathrm{W}}$ depends crucially on the way he has formulated $\mathrm{IPC}_{\mathrm{S}}$ and $\mathrm{IPC}_{\mathrm{W}}$. Recall that $\mathrm{PC}$ is actually a principle of propositional justification. In order to show that PC falls prey to his dilemma for internalism, Bergmann had to transform PC into a principle of doxastic justification. That is fair enough. But note that for most internalists-Huemer (2011a: 1) included-doxastic justification is simply a function of propositional justification plus proper basing (i.e., the belief that $p$ must actually be based upon one's propositional justification for $p$ ). ${ }^{10}$ But when Bergmann translates PC into its supposedly doxastic versions in $\mathrm{IPC}_{\mathrm{W}}$ and $\mathrm{IPC}_{\mathrm{S}}$, he fails to include a basing clause. It is possible that Bergmann took clause (3) of $\mathrm{IPC}_{\mathrm{S}}$ to be sufficient for basing, but surely it is not. That is, conceiving of a seeming that $p$ as being relevant to the truth or justification of the belief that $p$ is not sufficient for basing the belief that $p$ on the seeming that $p$. One could surely conceive of a seeming that $p$ as relevant but fail to have it enter into the evidence they actually use to support their belief that $p$. Just think of Lehrer's Gypsy Lawyer case (Lehrer 1971). A lawyer reads tarot cards to determine whether his client is guilty. The cards 'say' that he is guilty, so he goes out and finds evidence sufficient to conclude guilt. But the lawyer only collects evidence because his job requires it; he does not actually care about the evidence for epistemic reasons. He would believe with the cards and no evidence, and he would disbelieve with the evidence and no cards. Even though the lawyer is aware of the evidence and conceives of it as relevant to the proposition 'my client is guilty,' it seems clear that the lawyer is epistemically defective precisely because he does not base his belief in his client's guilt on the actual evidence. So, clause (3) of $\mathrm{IPC}_{\mathrm{S}}$ is insufficient for basing. But even if it were sufficient, IPC $\mathrm{W}_{\mathrm{W}}$ would still not contain a basing requirement. The point is this: Because neither $\mathrm{IPC}_{\mathrm{S}}$ nor $\mathrm{IPC}_{\mathrm{W}}$ includes a basing clause, $\mathrm{IPC}_{\mathrm{S}}$ and $\mathrm{IPC}_{\mathrm{W}}$ do not accurately reflect an internalist $\mathrm{PC}$ view of doxastic justification.

So let us include a basing clause in $\mathrm{IPC}_{\mathrm{W}}$, get a more accurate view of the weak version of internalist $\mathrm{PC}$, and re-evaluate.

(IPC $\left.\mathrm{W}_{2}\right)$ : $S$ 's belief that $p$ is prima facie justified only if(1) it seems to $S$ that $p$ and (2) $S$ is aware of this seeming (i.e., it is a conscious seeming); it is not necessary that (3) $\mathrm{S}$ conceives of this seeming that $p$ as being in some way relevant to the truth or justification of the belief that $p$; and (4) S must base the belief that $p$ upon S's seeming that $p$.

With this addition, it is clear that our hypothetical subject who severely malfunctions such that he has the seeming that $p$ but fails to base his belief that $p$ on his seeming that $p$ has some degree of propositional justification according to $\mathrm{PC}$ but is doxastically

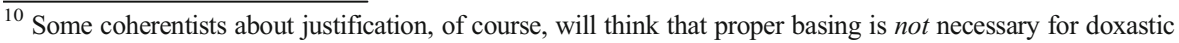
justification.
} 
unjustified, according to our IPC $\mathrm{W}_{\mathrm{W} 2}$. And this seems as it should be. If a subject has an epistemic reason to believe that $p$ (viz., it seems to the subject that $p$ ), then $p$ has some justification for that subject. But the subject's belief that $p$ might still be unjustified, depending on the subject's reason(s) for believing that $p$. To Bergmann's larger point, he is surely right that it is possible for $S$ to have a seeming that $p$ and at the same time for $S$ 's belief that $p$ to be accidentally true. But, this is only because $S$ 's belief that $p$ could be based upon bad evidence.

A quick aside: One might worry that by imposing a basing requirement $\mathrm{IPC}_{\mathrm{W} 2}$ can no longer do the work required of it. That is to say, because many accounts of the basing relation are doxastic and require that the subject believe that her evidence supports her conclusion (Audi 1993: 233-273; Fumerton 2004b: 165; Leite 2008), one might worry that $\mathrm{IPC}_{\mathrm{W} 2}$ cannot function as a solution to Bergmann's dilemma. After all, if IPC $_{\mathrm{W} 2}$ contains a higher-level doxastic requirement, then it seems that it just becomes a strong version of internalist PC and hence may fall victim to the first horn of Bergmann's dilemma. But by way of reply, note that the basing relation need not be doxastic. I do not have space to defend the view here, but I suggest that the basing requirement not be construed doxastically but in terms of a weaker requirement like $S$ takes evidence $E$ to support the proposition $p$ (cf. Tucker 2012). "Taking," is meant to encompass even non-doxastic states like seemings (and perhaps direct acquaintance, if it is construed as a non-doxastic state). ${ }^{11}$

Now let us return to the main point. Say that $S$ has a conscious seeming that $p$ and believes that $p$ on the basis of this seeming that $p$; that is, let us say that $S$ meets the conditions laid out in $\mathrm{IPC}_{\mathrm{W} 2}$. If $p$ turns out to be true, is it only accidentally true from $S$ 's perspective? This will depend on how we construe "accidentally true." Recall that Bergmann (2013: 168) understands this notion as follows:

(Accident V) It's false that it's an accident from $S$ 's perspective that her belief $B$ is true iff: $S$ is aware of $X$ and $S$ believes that $X$ indicates B's truth (or at least conceives of $X$ as being relevant to B's truth or justification).

Now if this is the only viable understanding of what it means for a proposition not to be accidentally true from a subject's perspective, then IPC ${ }_{\mathrm{W}}$ and $\mathrm{IPC}_{\mathrm{W} 2}$ are doomed to failure from the start. After all, weak internalist PC just denies that $S$ must conceive of $S$ 's seeming that $p$ as relevant to the truth of $S$ 's belief that $p$. But surely this is not the only viable understanding of what it means for a belief to fail to be accidentally true from a subject's perspective. We need a conception that captures Bergmann's (2006: 12) original intuition that an accidental belief is one that is no better than "a stray hunch or an arbitrary conviction." Rogers and Matheson (2011: 62) capture something of the commonsense notion of what it means for a belief not to be accidentally true when they write: "Given that the proposition seems true to him, it is not surprising or accidental, from his perspective, that it is true." The notion of 'not being surprising' is a good start. But we might ask why the truth that $p$ would be unsurprising to the subject. Well, presumably this is because the subject has a positive reason to believe that $p$ and no defeaters, no outweighing evidence. I suggest, then, that we capture this notion as follows:

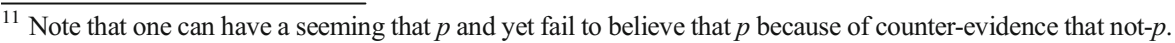


(Accident VI) It's false that it's an accident from $S$ 's perspective that her belief that $p$ is true iff: $S$ has an epistemic reason for her belief that $p$, bases her belief that $p$ on this epistemic reason, and has no believed defeaters for $p$.

The truth of the belief that $p$ is not surprising to $S$ because she has good reason to believe that $p$ (viz., $p$ seems true) and no outweighing reasons against $p$. Surely then the truth of $p$ is neither surprising nor accidental from $S$ 's perspective.

As a referee suggests, accident VI bears some resemblance to the first of the principles Bergmann considers:

(Accident I) It's false that it's an accident from $S$ 's perspective that her belief $B$ is true iff: $S$ is aware of $X$ and $X$ in fact indicates B's truth. (Bergmann 2013: 168)

Accident VI differs from Accident I, however, in focusing on epistemic reasons rather than awareness and includes basing and no-defeater clauses. Bergmann (2013: 168-169) rejected Accident I because he worried that it is "compatible with both (a) $S$ 's not realizing that the specified condition is satisfied and (b) $S$ 's believing that $B$ is formed in an unreliable way." Accident VI is subject to neither critique. Regarding (a), Bergmann's worry is that "a thing, $X$, of which $S$ is aware could indicate $B$ 's truth without $S$ realizing it does" (Bergmann 2013: 169). But Accident VI contains a basing clause. If $S$ possesses an epistemic reason for $B$ and then bases her belief $B$ on that reason, then $S$ clearly 'takes' her epistemic reason to indicate $B$ 's truth. And concerning (b), this is not an issue for Accident VI since it would constitute a believed defeater. Hence, Bergmann's concerns with Accident I do not apply to Accident VI.

To further see that Accident VI is indeed a good account, let us return to the case of Norman the clairvoyant (quoted above) which spawned this discussion of accidentally true beliefs. BonJour's critique of externalism, recall, is that Norman's belief is surely unjustified since he has no reason from his own perspective to believe that the President is in New York, even though Norman has a reliable clairvoyance mechanism. According to Accident VI, Norman's belief will indeed be accidentally true from his own perspective, given that BonJour (1985: 41) stipulated that Norman has no epistemic reason or evidence on which he bases his belief. So, Accident VI appears to jive with BonJour's internalist intuition about accidentally true beliefs.

The larger point is this: If Accident VI is (as it appears to be) a good account of what it means for a belief to fail to be accidentally true, then there seems no reason why $\mathrm{IPC}_{\mathrm{W} 2}$ must fall prey to the SPO. If a subject meets the conditions of IPC $\mathrm{W}_{\mathrm{W} 2}$, then the subject has also fulfilled the conditions for accident VI and hence her belief will not be accidentally true. For if one has a conscious seeming that $p$ and bases her belief that $p$ on the seeming (per $\mathrm{IPC}_{\mathrm{W} 2}$ ), then one has an epistemic reason to believe that $p$ upon which the belief is based (and, we are presuming, no defeaters). Hence fulfilling $\mathrm{IPC}_{\mathrm{W} 2}$ 's conditions will fulfill Accident VI's conditions. Consequently, $\mathrm{IPC}_{\mathrm{W} 2}$ does not fall prey to the SPO.

Huemer (2013a: 337) dismissed Bergmann's challenge from the SPO rather quickly; he thinks that the SPO is simply false if it is interpreted in a positive manner. For Huemer, the believing subject need not be aware of anything positive that the believed proposition has going for it in order to be justified; the subject must only be unaware of any defeaters. For him, the SPO is only true if it is posed as a negative requirement. But 
I have argued that the defender of PC need not deny the SPO. I have taken the SPO's claim that a subject must be "aware what a belief has going for it" in a straightforward manner as requiring that a subject must have positive epistemic reason(s) to believe the target proposition. Seemings appear to provide epistemic reasons, and Bergmann has not argued the contrary. ${ }^{12}$ Given this, internalist PC escapes the SPO horn of Bergmann's dilemma. ${ }^{13}$

\section{A Final Worry}

I have attempted to show that Bergmann's dilemma is unsuccessful against PC. In particular, I have argued that PC can avoid the SPO horn of his dilemma. But even if my argument here was unsuccessful, it is worth noting that the SPO horn of Bergmann's dilemma (see premise IV of Bergmann's dilemma, above) is ultimately about the internalist's motivation. The dilemma claims that because the only viable motivation for internalist PC is the SPO and internalist PC itself falls prey to the SPO, the motivation for internalist PC is lost.

But, while Bergmann has admittedly argued at some length that the SPO is the only good motivation for internalism (and hence the only good motivation for internalist PC), it is not at all clear that the SPO is the only viable motivation for internalism. Peter Markie (2009), for instance, has argued that while some of Bergmann's (2006) criticisms of leading motivations for internalism are successful, Bergmann still leaves some versions of internalism well-motivated. And I concur. There are many internalists who have sought to motivate internalism without invoking anything like the SPO. Michael Huemer (2011a) himself, to take but one example, seeks to motivate internalism with his self-defeat argument - a motivation quite independent of the SPO.

Now, it would be manifestly unfair to criticize Bergmann for having failed to refute every possible motivation for internalism other than the SPO. But still, the claim on which the second horn of the dilemma rests is that the SPO is the main motivation for internalism. Consequently, if Huemer or others have plausible motivations for their internalism beside the SPO, then Bergmann's dilemma will fail even if I have been incorrect in arguing that $\mathrm{PC}$ can meet the challenge of the SPO.

Acknowledgments The author wishes to thank Trent Dougherty, Ross Parker, and two anonymous referees for comments on previous versions of this paper. Thanks are also due to comments from attendees of the 2014 European Epistemology Network Meeting in Madrid, Spain, and attendees of the 2014 Joint Session of The Aristotelian Society and The Mind Association at Fitzwilliam College, Cambridge University.

\footnotetext{
${ }^{12}$ In fact, as Rogers and Matheson (2011: 61) have pointed out, Bergmann (2006) appears to accept the view that if a proposition $p$ seems true, then one thereby has a good reason to believe that $p$.

${ }^{13}$ It is also a consequence of my conclusion that Matthias Steup's recent revision of PC that he dubs "internalist reliabilism"- a revision which includes as a necessary condition on justification that one possess a memorial belief to the effect that one's seemings have a track record of reliability - is unnecessary (Steup 2004, 2013). On this view, seemings are not innocent until proven guilty. They need support from a track record of reliability. If my argument above is correct, PC can fend off Bergmann's dilemma without this addition.
} 


\section{References}

Audi, R. (1993). The structure of justification. New York: Cambridge University Press.

Bergmann, M. (2005). Defeaters and higher-level requirements. The Philosophical Quarterly, 55(220), 419436.

Bergmann, M. (2006). Justification without awareness: a defense of epistemic externalism. New York: Oxford University Press.

Bergmann, M. (2013). Phenomenal conservatism and the dilemma for internalism. In C. Tucker (Ed.), Seemings and justification: new essays on dogmatism and phenomenal conservatism (pp. 154-178). New York: Oxford University Press.

BonJour, L. (1978). Can empirical knowledge have a foundation? American Philosophical Quarterly, 15(1), $1-14$.

BonJour, L. (1985). The structure of empirical knowledge. Cambridge, MA: Harvard University Press.

BonJour, L. (2004). In search of direct realism. Philosophy and Phenomenological Research, 69(2), 349-367.

BonJour, L., \& Sosa, E. (2003). Epistemic justification: internalism vs. externalism, foundations vs. virtues. Malden, MA: Blackwell.

Cohen, S. (1984). Justification and truth. Philosophical Studies, 46(3), 279-295.

Conee, E., \& Feldman, R. (2004). Internalism defended. In E. Conee \& R. Feldman (Eds.), Evidentialism: essays in epistemology (pp. 53-82). New York: Oxford University Press.

Crisp, T. M. (2010). A dilemma for internalism? Synthese, 174(3), 355-366.

DePoe, J. M. (2012). Bergmann's dilemma and internalism's escape. Acta Analytica, 27(4), 409-423.

Fales, E. (1996). A defense of the given. Lanham: Rowman \& Littlefield Publishers.

Fales, E. (2014). Turtle epistemology. Philosophical Studies, 169(2), 339-354.

Fumerton, R. (1995). Studies in epistemology and cognitive theory. Lanham, MD: Rowman \& Littlefield. Metaepistemology and skepticism.

Fumerton, R. (2004a). Epistemic probability. Philosophical Issues, 14(1), 149-164.

Fumerton, R. (2004b). Inferential internalism and the presuppositions of skeptical arguments. In R. Schantz (Ed.), The externalist challenge (pp. 157-168). Walter de Gruyter: Berlin.

Current issues in theoretical philosophy.

Gage, L. P. (2014). Objectivity and subjectivity in epistemology: a defense of the phenomenal conception of evidence. Ph.D. Dissertation. Baylor University.

Huemer, M. (2001). Studies in epistemology and cognitive theory. Lanham, MD: Rowman \& Littlefield. Skepticism and the veil of perception.

Huemer, M. (2006). Phenomenal conservatism and the internalist intuition. American Philosophical Quarterly, 43(2), 147-158.

Huemer, M. (2007). Compassionate phenomenal conservatism. Philosophy and Phenomenological Research, $74(1), 30-55$.

Huemer, M. (2011a). Phenomenal conservatism and self-defeat: a reply to DePoe. Philosophical Studies, $156(1), 1-13$.

Huemer, M. (2011b). Epistemological egoism and agent-centered norms. In T. Dougherty (Ed.), Evidentialism and its discontents (pp. 17-33). New York: Oxford University Press.

Huemer, M. (2013a). Phenomenal conservatism über alles. In C. Tucker (Ed.), Seemings and justification: new essays on dogmatism and phenomenal conservatism (pp. 328-350). New York: Oxford University Press.

Huemer, M. (2013b). Phenomenal conservatism. Internet encyclopedia of philosophy. http://www.iep.utm. edu/phen-con/.

Lehrer, K. (1971). How reasons give us knowledge, or the case of the gypsy lawyer. The Journal of Philosophy, 68(10), 311-313.

Lehrer, K. (1990). Theory of knowledge. London: Routledge.

Leite, A. (2008). Believing one's reasons are good. Synthese, 161(3), 419-441.

Littlejohn, C. M. (2011). Defeating phenomenal conservatism. Analytic Philosophy, 52(1), 35-48.

Lyons, J. (2011). Circularity, reliability, and the cognitive penetrability of perception. Philosophical Issues, 21(1), 289-311.

Markie, P. (2005). The mystery of direct perceptual justification. Philosophical Studies, 126(3), 347-373.

Markie, P. (2006). Epistemically appropriate perceptual belief. Nô̂s, 40(1), 118-142.

Markie, P. (2009). Justification and awareness. Philosophical Studies, 146(3), 361-377.

McGrath, M. (2013). Phenomenal conservatism and cognitive penetration: the 'bad basis' counterexamples. In C. Tucker (Ed.), Seemings and justification: new essays on dogmatism and phenomenal conservatism (pp. 225-247). New York: Oxford University Press. 
Moser, P. K. (1985). Empirical justification. Boston, MA: D. Reidel Pub. Co.

Rogers, J., \& Matheson, J. (2011). Bergmann's dilemma: exit strategies for internalists. Philosophical Studies, $152(1), 55-80$.

Sellars, W. (1963). Empiricism and the philosophy of mind. In Science, perception and reality (pp. 127-196). London: Routledge \& Kegan Paul.

Sellars, W. (1975). The structure of knowledge. In H.-N. Castañeda (Ed.), Action, knowledge and reality: critical studies in honor of Wilfrid Sellars (pp. 295-347). Indianapolis: Bobbs-Merrill.

Siegel, S. (2013). The epistemic impact of the etiology of experience. Philosophical Studies, 162(3), 697-722.

Steup, M. (2004). Internalist Reliabilism. Philosophical Issues, 14, 403-425.

Steup, M. (2013). Does phenomenal conservatism solve internalism's dilemma? In C. Tucker (Ed.), Seemings and justification: new essays on dogmatism and phenomenal conservatism (pp. 135-153). New York: Oxford University Press.

Tolhurst, W. (1998). Seemings. American Philosophical Quarterly, 35(3), 293-302.

Tooley, M. (2013). Michael Huemer and the principle of phenomenal conservatism. In C. Tucker (Ed.), Seemings and justification: new essays on dogmatism and phenomenal conservatism (pp. 306-327). New York: Oxford University Press.

Tucker, C. (2012). Movin' on up: higher-level requirements and inferential justification. Philosophical Studies, 157(3), 323-340. 